\title{
PERSPECTIVES ON KNOWLEDGE MANAGEMENT APPLICATION IN BPPT LIBRARY AS AN ORGANIZATIONAL KNOWLEDGE COLLECTION PLATFORM
}

\author{
Ria Ariani ${ }^{1}$, Rasty Ucyari ${ }^{2}$, dan Lisda Rahayu ${ }^{3}$ \\ ${ }^{1,2,3}$ Badan Pengkajian dan Penerapan Teknologi (BPPT)
}

*Correspondence: ria.ariani@bppt.go.id; rasty.ucyari@bppt.go.id; lisda.rahayu@bppt.go.id

\begin{abstract}
This study evaluates the practice of a knowledge management system through the knowledge management application used by the Agency for the Assessment and Application of Technology (BPPT). The purpose of this study is to understand and get an overview from BPPT employees related to BPPT knowledge management (KM) application in its function as an organizational knowledge collection platform. This study is hopefully beneficial to see the effectiveness of the features of KM application in supporting the work activities of BPPT employees. The method used in this research is quantitative, using a questionnaire technique based on a survey to gather the data. The questionnaire was distributed to employees who are the administrator of the KM BPPT application from each BPPT working unit. The collected data were processed and analyzed using the AIDA model. This study indicates that BPPT employees have used the BPPT KM application, and some of the features also have been used, such as chats, tasks, drives, and events. Moreover, based on the results obtained, it is known that BPPT employees trust the app and consider the BPPT KM application reliable to store and manage organizational knowledge properly.
\end{abstract}

\begin{abstract}
ABSTRAK
Dalam kajian ini dilakukan praktik evaluasi dari penerapan knowledge management system melalui aplikasi knowledge management yang digunakan oleh Badan Pengkajian dan Penerapan Teknologi (BPPT). Tujuan dari penelitian ini adalah untuk mengetahui dan mendapatkan gambaran dari para pegawai BPPT terkait pemanfaatan aplikasi knowledge management (KM) BPPT dalam fungsinya sebagai platform pengumpulan pengetahuan organisasi. Studi ini berguna dalam mengevaluasi efektifitas fitur-fitur yang ada dalam aplikasi knowledge management BPPT dalam mendukung kegiatan dan aktifitas pegawai BPPT. Adapun metode yang digunakan dalam penelitian ini adalah kuantitatif dengan menggunakan teknik penyebaran kuesioner yang didasarkan pada survei dalam mengumpulkan data. Kuesioner disebarkan kepada pegawai yang merupakan administrator unit kerja utuk aplikasi KM BPPT. Data yang dikumpulkan diolah dan dianalisis menggunakan AIDA model. Hasil dari penelitian ini mengindikasi bahwa aplikasi KM BPPT sudah secara majoritas digunakan oleh pegawai BPPT dan fitur yang ada didalamnya juga sudah dimanfaatkan seperti: chats \& calls, task, drive dan event. Juga, berdasarkan hasil yang diperoleh diketahui bahwa pegawai BPPT telah percaya dan menganggap aplikasi KM BPPT ini dapat menyimpan dan mengelola pengetahuan organisasi dengan baik.
\end{abstract}

Keywords: Knowledge management; Agency for the Assessment and Application of Technology (BPPT); Knowledge management application; Knowledge collection; AIDA model.

\section{INTRODUCTION}

Knowledge is one of an organization's most valuable assets (Gharamah et al. 2018). In an organization, knowledge can be created in the form of information processed into new knowledge, knowledge held by the organization's human resources, and experiences with a strong practical value (Igbinovia and Ikenwe 2018). An organization's productivity will increase if knowledge is managed effectively. Knowledge can be the organization's most essential asset and a crucial tool for ensuring its survival and increasing its competitiveness (Omotayo 2015).

Institutions require knowledge management (KM) to safeguard intellectual assets and help create value inside the organization (Hebibi, Raimi, and Milićićević 2019). The chances of 
attaining success are even better if an organization has strong knowledge management. By seeing the importance of the role of knowledge in an organization, an organization must be able to manage knowledge well to increase organizational productivity.

Badan Pengkajian dan Penerapan Teknologi (BPPT) as a non-ministerial government agency under Badan Riset dan Inovasi Nasional Republik Indonesia (BRIN), where the main task and function is conducting an assessment of the application of technology in Indonesia, certainly has several essential knowledge assets, both explicit knowledge and tacit knowledge. For that reason, BPPT needs to understand how knowledge is created, shared and used. Therefore, BPPT develops a knowledge-based application called the Knowledge Management Application (KM BPPT) to manage the knowledge developed and held by the organization. The BPPT Library manages this KM BPPT application, which was created to manage the institution's knowledge assets. The application provides access for BPPT employees to manage knowledge, both in terms of sharing knowledge and storing knowledge for quick access to information and organizational knowledge.

Employees actively used the KM BPPT application in early 2020. In March 2020, Indonesia experienced a COVID-19 pandemic, an ongoing virus outbreak around the world. In order to stop the chain of COVID-19 infections, the Indonesian government has made a policy of Large-Scale Social Restrictions (PSBB) in which social movements of the community are restricted. This policy forces all government institutions to implement the Work From Home (WFH) working system. All BPPT workers are encouraged to use the KM BPPT application, which is administered by the BPPT Library, to manage and accumulate organizational knowledge to support the WFH working system. As a result, it is hoped that the knowledge assets developed and produced by BPPT employees could be documented in a knowledge-based application and that BPPT employees will be able to share their knowledge over the network. Based on these reasons, this study is conducted to acknowledge the perspectives of BPPT employees on the effectiveness of the features in this $\mathrm{KM}$ application in supporting their activities and the effectiveness of managing and collecting knowledge through the BPPT KM application.

\section{METHOD}

This study uses a quantitative method with a survey approach using a questionnaire delivered to BPPT employees. Lavrakas (2008) claimed that questionnaires effectively assess community behavior toward specific entities in quantitative research. Questionnaires were utilized in this study to assess BPPT workers' behavior and perspectives on the KM application. Respondents who took part in this study are BPPT employees who are also the KM application administrators of each BPPT working unit. There are 43 work units at BPPT, divided into Pusat, Biro, Balai, and Balai Besar, as shown in Table 1.

Table 1. BPPT working unit demographic

\begin{tabular}{|c|c|c|c|}
\hline Biro Name & Pusat Name & Balai Name & Balai Besar Name \\
\hline $\begin{array}{c}\text { Biro Perencanaan } \\
\text { dan Keuangan }\end{array}$ & Pusat Pelayanan Teknologi & $\begin{array}{c}\text { Balai Teknologi } \\
\text { Mesin Perkakas, } \\
\text { Produksi dan } \\
\text { Otomasi }\end{array}$ & $\begin{array}{c}\text { Balai Besar Teknologi } \\
\text { Aerodinamika, Aeroelastika } \\
\text { dan Aeroakustika }\end{array}$ \\
\hline $\begin{array}{c}\text { Biro SDM dan } \\
\text { Organisasi }\end{array}$ & $\begin{array}{c}\text { Pusat Pembinaan, Pendidikan dan } \\
\text { Pelatihan }\end{array}$ & $\begin{array}{c}\text { Balai Teknologi } \\
\text { Termodinamika, } \\
\text { Motor dan Propulsi }\end{array}$ & $\begin{array}{c}\text { Balai Besar Teknologi } \\
\text { Kekuatan Struktur }\end{array}$ \\
\hline $\begin{array}{c}\text { Biro Hukum, } \\
\text { Kerjasama dan } \\
\text { Humas }\end{array}$ & Pusat Manajemen Informasi & $\begin{array}{c}\text { Balai Teknologi } \\
\text { Hidrodinamika }\end{array}$ & $\begin{array}{c}\text { Balai Besar Teknologi } \\
\text { Konversi Energi }\end{array}$ \\
\hline
\end{tabular}




\begin{tabular}{|c|c|c|c|}
\hline Biro Umum & $\begin{array}{l}\text { Pusat Teknologi Kawasan } \\
\text { Spesifik dan Sistem Inovasi }\end{array}$ & $\begin{array}{l}\text { Balai Teknologi } \\
\text { Infrastruktur, } \\
\text { Pelabuhan dan } \\
\text { Dinamika Pantai }\end{array}$ & Balai Besar Teknologi Pat \\
\hline & $\begin{array}{l}\text { Pusat Pengkajian Industri Proses } \\
\text { dan Energi }\end{array}$ & $\begin{array}{l}\text { Balai Teknologi } \\
\text { Bahan Bakar dan } \\
\text { Rekayasa Desain }\end{array}$ & $\begin{array}{l}\text { Balai Besar Teknologi } \\
\text { Modifikasi Cuaca }\end{array}$ \\
\hline & $\begin{array}{c}\text { Pusat Pengkajian Industri } \\
\text { Manufaktur, Telematika dan } \\
\text { Elektronika }\end{array}$ & $\begin{array}{c}\text { Balai Jaringan } \\
\text { Informasi dan } \\
\text { Komunikasi }\end{array}$ & \\
\hline & Pusat Sistem Audit Teknologi & $\begin{array}{l}\text { Balai Teknologi } \\
\text { Polimer }\end{array}$ & \\
\hline & $\begin{array}{l}\text { Pusat Teknologi Pengembangan } \\
\text { Sumberdaya Wilayah }\end{array}$ & Balai Bioteknologi & \\
\hline & $\begin{array}{c}\text { Pusat Teknologi Pengembangan } \\
\text { Sumberdaya Mineral }\end{array}$ & $\begin{array}{l}\text { Balai Teknologi } \\
\text { Survei Kelautan }\end{array}$ & \\
\hline & $\begin{array}{c}\text { Pusat Teknologi Reduksi Risiko } \\
\text { Bencana }\end{array}$ & $\begin{array}{l}\text { Balai Inkubator } \\
\text { Teknologi }\end{array}$ & \\
\hline & Pusat Teknologi Lingkungan & $\begin{array}{l}\text { Balai Teknologi } \\
\text { Industri Kreatif } \\
\text { Keramik }\end{array}$ & \\
\hline & $\begin{array}{c}\text { Pusat Teknologi Produksi } \\
\text { Pertanian }\end{array}$ & & \\
\hline & Pusat Teknologi Agroindustri & & \\
\hline & Pusat Teknologi Bioindustri & & \\
\hline & $\begin{array}{l}\text { Pusat Teknologi Farmasi dan } \\
\text { Medika }\end{array}$ & & \\
\hline & Pusat Teknologi Elektronika & & \\
\hline & $\begin{array}{l}\text { Pusat Teknologi Sumberdaya } \\
\text { Energi dan Industri Kimia }\end{array}$ & & \\
\hline & $\begin{array}{c}\text { Pusat Teknologi Informasi dan } \\
\text { Komunikasi }\end{array}$ & & \\
\hline & Pusat Teknologi Material & & \\
\hline & $\begin{array}{l}\text { Pusat Teknologi Industri } \\
\text { Pertahanan dan Keamanan }\end{array}$ & & \\
\hline & $\begin{array}{l}\text { Pusat Teknologi Industri } \\
\text { Permesinan }\end{array}$ & & \\
\hline & $\begin{array}{l}\text { Pusat Teknologi Sistem dan } \\
\text { Prasarana Transportasi }\end{array}$ & & \\
\hline & $\begin{array}{c}\text { Pusat Teknologi Rekayasa } \\
\text { Industri Maritim }\end{array}$ & & \\
\hline 4 & 23 & 11 & 5 \\
\hline
\end{tabular}

Purposive sampling was utilized to acquire data for the questionnaire survey. Purposive sampling is a technique for selecting informants with a specific goal in mind or to acquire highquality data in a field where the informant already has the experience and knowledge about it (Dolores and Tongco 2007). A survey's questions addressed issues connected to the study's aims, topics, and subjects (Lavrakas 2008). The questions in this research are, of course, relevant to the BPPT KM application and include employee understanding of the features in the KM application, workgroup activity in the KM application, the use of features in the KM application, security data on the KM applications and expectations on the KM application development. The questionnaire was completed online using Google Forms. All of the questions were rated on a scale ranging from 
strongly disagree to strongly agree and never to frequently, then translated to a Likert scale. For data analysis, this study employs the AIDA model (attention, interest, desire, and action), which was popularized by Kotler and Keller (2012). This model is considered appropriate because it can be used to understand and identify the level of impact and effectiveness of the KM applications on BPPT employees organizational knowledge management. Moreover, it can discover related issues to attract users and know their interest to act (Michaelson and Stacks 2011). Pashootanizadeh \& Khalilian (2018) also stated that the AIDA model could assist in determining a program's or object's efficiency.

\section{RESULTS AND DISCUSSION}

\subsection{Survey Results}

Based on a survey that has been distributed to 43 respondents (the KM application administrators who are also representatives of each working unit at BPPT), only 13 people responded to a survey sent out to them and answered online questionnaires via Google Forms. Table 2 depicts the demographic distribution of respondents in this study based on gender and BPPT deputies.

Table 2. Respondents demographic

\begin{tabular}{|l|l|}
\hline Demographic variable & Percentage \\
\hline Gender & $54 \%$ \\
\hline Men & $46 \%$ \\
\hline Women & $23 \%$ \\
\hline Deputy & $15.5 \%$ \\
\hline Technology Policy (PKT) & $23 \%$ \\
\hline Technology of Natural Resource Development (TPSA) & $23 \%$ \\
\hline Technology of Agroindustry dan Biotechnology (TAB) & $15.5 \%$ \\
\hline $\begin{array}{l}\text { Technology of Information, Energy and Materials } \\
\text { (TIEM) }\end{array}$ & $\begin{array}{l}\text { Technology of Engineering and Design Industry } \\
\text { (TIRBR) }\end{array}$ \\
\hline
\end{tabular}

Males accounted for 54 per cent of the 13 questions completed by respondents, while females accounted for 46 per cent. In general, respondents surveyed have a sufficient and competent understanding of the BPPT KM application because each BPPT KM administrator had previously been trained regarding the management of this KM application. Furthermore, the percentage of respondents from the Deputy for Technology Policy (PKT), Agroindustry and Biotechnology Technology (TAB) and Information Technology, Energy and Materials (TIEM) is 23 per cent. Meanwhile, the Deputy for Natural Resources Development Technology (TPSA) and Technology of Engineering and Design Industry (TIRBR) response was 15.5 per cent.

The questionnaire distributed to BPPT employee respondents was divided into 15 questions covering the understanding of the KM applications, utilization of the KM applications, the trustworthiness of using the KM applications and threats to the KM applications. Table 3 shows the structure of this survey's questionnaire.

Table 3. Questionnaire Form

\begin{tabular}{|l|l|l|l|l|l|l|}
\hline No. & Questions & $\mathbf{1}$ & $\mathbf{2}$ & $\mathbf{3}$ & $\mathbf{4}$ & $\mathbf{5}$ \\
\hline 1 & $\begin{array}{l}\text { Understanding for KM feature of MESSAGE } \\
\text { (activity stream) }\end{array}$ & & & & & \\
\hline
\end{tabular}




\begin{tabular}{|l|l|l|l|l|l|l|}
\hline 2 & Understanding for KM feature of DISCUSSION & & & & & \\
\hline 3 & Understanding for KM feature of CHAT \& CALLS & & & & & \\
\hline 4 & Understanding for KM feature of TASKS & & & & & \\
\hline 6 & Understanding for KM feature of EVENT & & & & & \\
\hline 6 & Understanding for KM feature of DRIVE & & & & & \\
\hline 7 & Usage of KM feature MESSAGE (activity stream) & & & & & \\
\hline 8 & Usage of KM feature DISCUSSION & & & & & \\
\hline 9 & Usage of KM feature CHAT \& CALLS & & & & & \\
\hline 10 & Usage of KM feature TASKS & & & & & \\
\hline 11 & Usage of KM feature EVENT & & & & & \\
\hline 12 & Usage of KM feature DRIVE & & & & & \\
\hline 13 & Workgroup activity in KM application & & & & & \\
\hline 14 & I trust storing data in the KM BPPT application & & & & & \\
\hline 15 & Security threats for KM BPPT application & & & & & \\
\hline
\end{tabular}

From the questions in Table 3, the data were processed using a Likert scale of 1-5. Boone, Jr. and Boone (2012) stated that utilizing a Likert scale to analyze can provide descriptive statistics that will be very beneficial throughout the data analysis stage to reach appropriate decisions or conclusions. Then, the questionnaire's value scale range is then determined as follows:

Table 4. Value range

\begin{tabular}{|l|l|}
\hline Category & Scale \\
\hline Low & $(1,00-2)$ \\
\hline Medium & $(2,00-3)$ \\
\hline High & $(3,00-5)$ \\
\hline
\end{tabular}

Based on the score scale above, each question in the questionnaire is assessed on a scale of 1-5, which consists of fifteen questions, which include employee understanding of the features of the KM BPPT application, such as messages (activity streams), discussions, chat \& calls, tasks, events, and drives. Employee comprehension of these KM application functionalities or features can also be observed with this scale. Then, issues such as trust in KM applications for storing knowledge, workgroup activity in KM application, and dangers in the application are also assessed. The results of the questionnaire and survey are shown in Table 5.

Table 5. Questionnaire results

\begin{tabular}{|l|l|l|}
\hline No. & Questions & Value \\
\hline $\mathbf{1}$ & $\begin{array}{l}\text { Understanding for KM feature of MESSAGE } \\
\text { (acitivity stream) }\end{array}$ & 4,3 \\
\hline $\mathbf{2}$ & Understanding for KM feature of DISCUSSION & 3,25 \\
\hline $\mathbf{3}$ & Understanding for KM feature of CHAT \& CALLS & 3,25 \\
\hline $\mathbf{4}$ & Understanding for KM feature of TASKS & 3,25 \\
\hline $\mathbf{5}$ & Understanding for KM feature of EVENT & 3,25 \\
\hline $\mathbf{6}$ & Understanding for KM feature of DRIVE & 3,25 \\
\hline $\mathbf{7}$ & Usage of KM feature MESSAGE (activity stream) & 3,25 \\
\hline
\end{tabular}




\begin{tabular}{|l|l|l|}
\hline $\mathbf{8}$ & Usage of KM feature DISCUSSION & 1,2 \\
\hline $\mathbf{9}$ & Usage of KM feature CHAT \& CALLS & 2,6 \\
\hline $\mathbf{1 0}$ & Usage of KM feature TASKS & 3,25 \\
\hline $\mathbf{1 1}$ & Usage of KM feature EVENT & 2,6 \\
\hline $\mathbf{1 2}$ & Usage of KM feature DRIVE & 3,25 \\
\hline $\mathbf{1 3}$ & Workgroup activity in KM application & 3,25 \\
\hline $\mathbf{1 4}$ & I trust storing data in KM BPPT application & 4,3 \\
\hline $\mathbf{1 5}$ & Security treats for KM BPPT application & 1,54 \\
\hline
\end{tabular}

Using the Likert scale mentioned by Boone, Jr. and Boone (2012), the assessed questions consist of: employee understanding of the message (activity stream), discussion, chat \& calls, tasks, events and drives features; message usage (activity stream), discussion, chat \& calls, tasks, events and drives features; workgroup activity in the $\mathrm{KM}$ application; trust for data storage in the $\mathrm{KM}$ BPPT application; and data security threats to the KM applications. Furthermore, as shown in Table 5, the aspects in the low category are the use of discussion features with a value of 1.2 and data security threats in the KM applications with 1.54 . Moreover, it can be seen in table 5 that employees' understanding of the message feature (activity stream) and employee trust in storing data in the KM BPPT application are aspects that are considered very high, with a value of 4.3. It represents that most BPPT employees trust and consider this KM application reliable in storing organizational knowledge.

If we see from Table 5, the results are shown in Figure 1 regarding the graph of the questionnaire scores obtained as follows:

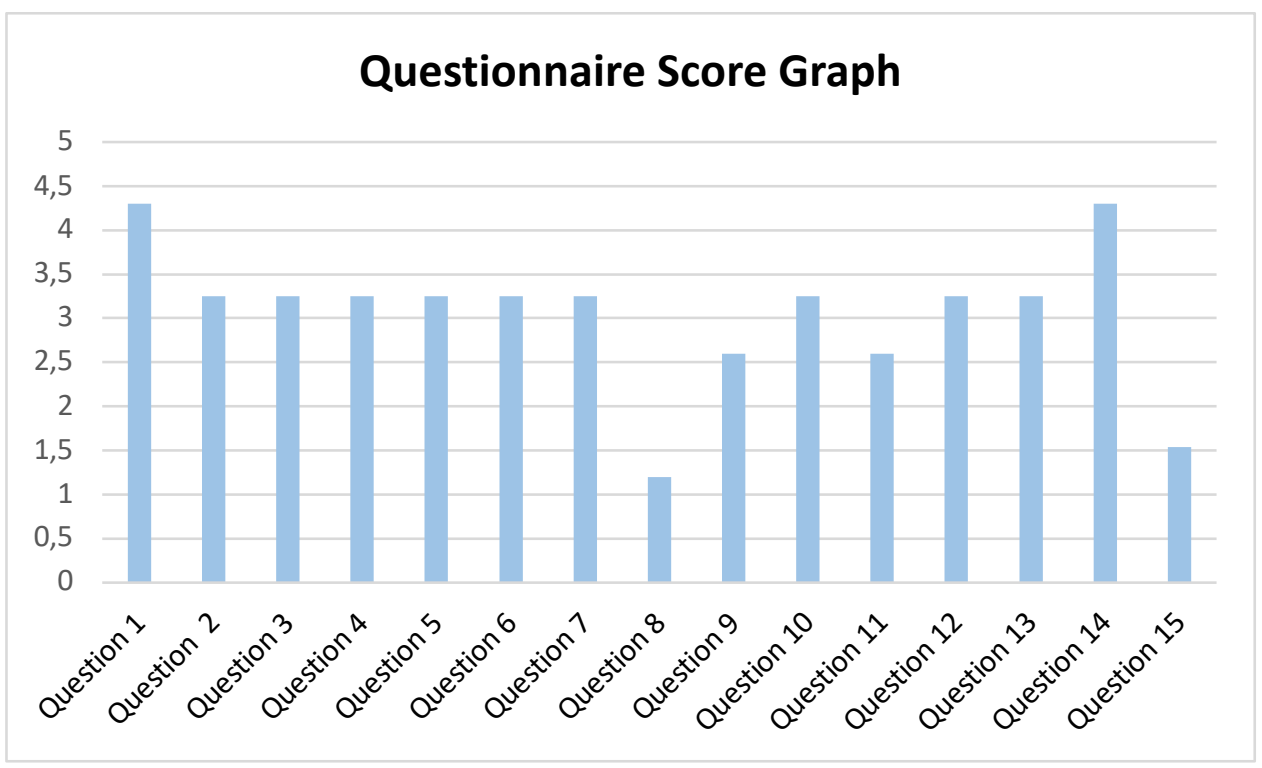

Figure 1. Questionnaire score graph

The value of the questionnaire's questions is analyzed based on the graph above to acquire an idea from the perspective of BPPT employees as to what features of the BPPT KM application are of concern. The graph results in Figure 1 show that question 1 and question 14 have the highest scores, namely: employee understanding of the message feature (activity stream) and trust in storing data in the KM application. As shown in Figure 1, the majority of BPPT employees believe in using this application. Employees' understanding of the feature of MESSAGE (activity stream) 
is believed to be extremely strong. Therefore, the menu or feature of MESSAGE (activity stream) is also thought to have captivated their interest.

On the other hand, question 8 about using the discussion feature in the KM application has the lowest score and should be a reason for further evaluation. From this data, the discussion feature is known as a gap for this research that the KM application team must explore further. The lack of this feature usage requires a further evaluation from the KM application manager at the BPPT Library, and it is necessary to think about steps and strategies so that BPPT employees can make better use of this feature later in the future. Question no.15, addressing data security issues in the $\mathrm{KM}$ application, is the second-lowest aspect after question 8. From question 15, BPPT employees believe that data security in the KM application is a critical issue that needs to be addressed so that the management and team responsible for this application can regularly monitor and evaluate the data security in the KM application.

Moreover, other than the discussion menu on the KM application, the usage and utilization of features reviews have been quite positive. As depicted in Figure 1, features such as messages (activity stream), tasks and drives have a utilization value of 3.25 and are included in the high category value range (Table 4). Meanwhile, with a value of only 2.6 , the chat $\&$ calls and event features fall into the medium group. Then, for understanding the features in the KM application, all existing features have received a high score with a minimum value range of 3.25 for all of its features. Then, for workgroup activity in the KM application, it is also rated high with a value of 3.25 and has been actively used by BPPT employees.

\subsection{Results Analysis Using AIDA Model}

The results of this study, which relate to the user's perspective on the KM BPPT application, were used to explore each stage in the AIDA model. A table has been created that links components of the AIDA model to the survey questions as follows:

Table 6. Relationship of Survey Results and AIDA Model

\begin{tabular}{|l|l|}
\hline Survey results & AIDA aspects \\
\hline $\begin{array}{l}\text { Understanding for KM feature of MESSAGE } \\
\text { (acitivity stream) }\end{array}$ & Interest \\
\hline Understanding for KM feature of DISCUSSION & Interest \\
\hline $\begin{array}{l}\text { Understanding for KM feature of CHAT \& } \\
\text { CALLS }\end{array}$ & Interest \\
\hline Understanding for KM feature of TASKS & Interest \\
\hline Understanding for KM feature of EVENT & Interest \\
\hline Understanding for KM feature of DRIVE & Interest \\
\hline $\begin{array}{l}\text { Usage of KM feature MESSAGE (activity } \\
\text { stream) }\end{array}$ & Action \\
\hline Usage of KM feature DISCUSSION & Action \\
\hline Usage of KM feature CHAT \& CALLS & Action \\
\hline Usage of KM feature TASKS & Action \\
\hline Usage of KM feature EVENT & Action \\
\hline Usage of KM feature DRIVE & Action \\
\hline Workgroup activity in KM application & Action \\
\hline I trust storing data in the KM BPPT application & Desire \\
\hline Security threats for KM BPPT application & Attention \\
\hline
\end{tabular}


As explained in the previous section, Kotler \& Keller (2012) explained four aspects of the AIDA model. From the data obtained in Table 5, the relationship aspects of Attention, Desire, Interest and Action associated with the questions contained in the survey questionnaire in this study are described in Table 6. Furthermore, as shown in Table 6, questions related to BPPT employees' understanding of the message (activity stream), discussion, chat \& calls, tasks, events, and drive features are categorized to Interest aspect in the AIDA model. It is included in the Interest category because, according to Michaelson \& Stacks (2011), there should be a willingness to study and examine the features of the KM application. Likewise, most BPPT employees are considered to have a good understanding of the six features in the KM BPPT application, and they are expected to be able to manage knowledge effectively using these features in the next stage.

From Table 6, it shows that the six elements of this KM application have been well utilized, with question 7 relating to the use of the message (activity stream) feature until question 13 relating to workgroup activity are classified under the Action aspect because the act of the KM application has been carried out by users, in this case, BPPT employees. It has led them to use the KM application features (Rehman et al., 2015), where the value of workgroup activity in the application is also considered relatively high (Table 5).

Following that, the Desire aspect may be viewed in the KM BPPT application's data storage trustworthiness. It is because application users have been directed to utilize it, and it is conceivable that the application will be used to store organizational data and knowledge from BPPT employees (Ghirvu 2013). After that, in Table 5, question 15, which is about data security issues in the KM applications, the Attention element can be seen. It is because application users have looked about how their knowledge is stored and handled safely in this KM application.

\section{CONCLUSION}

According to the study's findings, most respondents are familiar with and have utilized the functionalities and features of the KM application. Men made up 54 per cent of the total participants, while women made up 46 per cent. The survey results show that the relationship between AIDA aspects (Attention, Desire, Interest and Action) can be seen in the questionnaire form's questions. The results reveal that the security of the KM application grabbed users' attention, as seen by question 15, with a score of 1.54 . Next, with a value of 4.3 in question 14 , most BPPT workers believe in storing data in the KM application. Questions 1 to 6 indicate the interest component, with an average score of 3.25 indicating that BPPT employees have a good understanding of the KM application's functionalities. Then, from question 7 through question 13, the Action aspect can be seen, where employees have actively used the capabilities and existing workgroups in the KM application, with an average survey score of $>3$.

The study results show that BPPT employees have a positive perception about the KM application provided by the BPPT Library and that most employees already trust and rely on it. To enrich the study analysis, we suggest future research to look into how institution regulation affects the implementation of the KM applications in BPPT, as well as what aspects make this application more appealing to use so that a comprehensive understanding of the BPPT KM application can be obtained to support its successful implementation. In addition, our study is restricted to internal users, specifically BPPT employees. Future studies may be able to cover potential uses of this application for the public and private sectors. 


\section{ACKNOWLEDGMENTS}

Our gratitude goes to all BPPT KM Application Team and Pusat Manajemen Informasi Badan Pengkajian dan Penerapan Teknologi for all the help, data and technical knowledge to support this research.

\section{BIBLIOGRAPHY}

Boone, Jr., Harry N., and Deborah A. Boone. 2012. "Analyzing Likert Data." Journal of Extension 50 (2): 1456-66. https://doi.org/10.1007/s11172-017-1908-3.

Dolores, Ma., and C. Tongco. 2007. "Purposive Sampling as a Tool for Informant Selection." Ethnobotany Research and Applications 5: 147-58. https://doi.org/10.17348/era.5.0.147-158.

Gharamah, Abdulrahman, Mohamad Fauzan Noordin, Najma Imtiaz Ali, and Imtiaz Ali Brohi. 2018. "Approach for Successful Knowledge Management System Deployment for Organizations." International Journal of Engineering and Technology(UAE) 7 (2): 74-78. https://doi.org/10.14419/ijet.v7i2.34.13916.

Ghirvu, Alina Irina. 2013. "The Aida Model for Advergames." USV Annals of Economics and Public Administration 13 (1(17)): 90-98.

Hebibi, Lokman, Naser Raimi, and Raica Milićićević. 2019. "Knowledge Management and the Importance of Knowledge Management for the Organization's Performance." Ekonomika 65 (1): 117-26. https://doi.org/10.5937/ekonomika1901117h.

Igbinovia, Magnus O., and Iguehi J. Ikenwe. 2018. "Knowledge Management: Processes and Systems." Information Impact: Journal of Information and Knowledge Management 8 (3): 26. https://doi.org/10.4314/iijikm.v8i3.3.

Kotler, Philip, and Kevin Lane Keller. 2012. Marketing Management 14th Ed. New Jersey: Pearson Education, Inc. https://doi.org/10.1017/cbo9781139174749.022.

Lavrakas, Paul J. 2008. Encyclopedia of Survey Research Methods. Journal of Visual Languages \& Computing. California: SAGE Publications, Inc. https://www.mculture.go.th/mculture_th/download/king9/Glossary_about_HM_King_Bhumibol_Adulyadej's_ Funeral.pdf.

Michaelson, David, and Don W Stacks. 2011. "Standardization in Public Relations Measurement and Evaluation.” Public Relations Journal 5 (2): 1-22. http://www.prsa.org/SearchResults/view/6D050201/0/Standardization_in_Public_Relations_Measurement_an.

Omotayo, Funmilola Olubunmi. 2015. "Knowledge Management As an Important Tool in Organisational Management: A Review Of." Library Philosophy and Practice 4 (10): 1-23. http://digitalcommons.unl.edu/libphilprachttp://digitalcommons.unl.edu/libphilprac/1238.

Pashootanizadeh, Mitra, and Saideh Khalilian. 2018. "Application of the AIDA Model: Measuring the Effectiveness of Television Programs in Encouraging Teenagers to Use Public Libraries." Information and Learning Science 119 (11): 635-51. https://doi.org/10.1108/ILS-04-2018-0028.

Rehman, Fazal ur, Farwida Javed, Shabir Hyder, and Sadaqat Ali. 2015. "A Qualitative Approach to Analyze Marketing Communication Based on AIDA Model." Information Management and Business Review 7 (5): 44-54. 